\title{
Pengintegrasian penilaian formatif dalam pembelajaran IPA berbasis saintifik terhadap pemahaman konsep peserta didik
}

\author{
Intan Puspita Sari ${ }^{1}$, Vita Ria Mustikasari ${ }^{2 *}$, Novida Pratiwi ${ }^{3}$ \\ Pendidikan IPA, Fakultas Matematikan dan Ilmu Pengetahuan Alam, Universitas Negeri Malang, \\ Malang, Jawa Timur, Indonesia \\ *Coressponding author email: vita.ria.fmipa@um.ac.id
}

\section{Artikel info \\ Received : 04 Februari 2019 \\ Revised : 10 April 2019 \\ Accepted : 20 April 2019}

\section{Kata kunci:}

Pemahaman konsep

Pendekatan saintifik

Penilaian formatif

\begin{abstract}
ABSTRAK
Tercapainya tujuan pembelajaran IPA dapat diketahui dengan melakukan penilaian yang merupakan salah satu prinsip pengembangan kurikulum 2013. Penelitian ini bertujuan untuk mengetahui pengaruh pengintegrasian penilaian formatif dalam pembelajaran IPA berbasis pendekatan saintifik terhadap pemahaman konsep peserta didik. Penelitian ini dilaksanakan di SMPN 3 Trenggalek kelas VIII tahun pelajaran 2017/2018 mata pelajaran Ilmu Pengetahuan Alam. Metode penelitian yang digunakan adalah quasyexperimental dengan desain penelitian posttest control group design. Hasil analisis data uji-t two tailed dengan $\alpha=0,05$, nilai $p<0,05$, yang menyatakan bahwa terdapat perbedaan pemahaman konsep yang signifikan pada kelas kontrol dan kelas eksperimen. Berdasarkan hasil penelitian disimpulkan bahwa pengintegrasian penilaian formatif formal dan informal dalam pembelajaran IPA berbasis pendekatan saintifik memberikan pengaruh yang signifikan terhadap peningkatan pemahaman konsep peserta didik.
\end{abstract}

\section{ABSTRACT}

Keywords:

Scientific approach

Conceptual understanding

Formative assessment

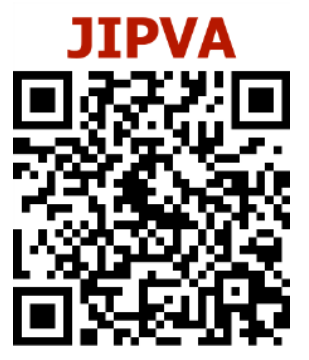

Formative assessment integration in science learning based on scientific approach toward student conceptual understanding. The achievement of science learning goals can be known by conducting an assessment which is one of the principles of 2013 curriculum development. This study aims to invesitgate the effect of integrating formative assessment in science learning based on a scientific approach to understand the students' concepts. This research was conducted at VIII grade of SMPN 3 Trenggalek academic year of 2017/2018 in a science lesson. The quasi-experimental research method with posttest control group design was used. The two-tailed t-test result shown at $\alpha=0.05, p<0.05$ which means indicate the significant difference between control and experiment class. It can conclude that integrated formal and informal formative assessment in science learning based on scientific approach has a significant effect on the students' conceptual understanding improvement.

How to Cite : Sari, I.P., Mustikasari, V.R., \& Novida, P. (2019). Pengintegrasian penilaian formatif dalam pembelajaran IPA berbasis saintifik terhadap pemahaman konsep peserta didik. JIPVA (Jurnal Pendidikan IPA Veteran), 3(1), 51-61. doi: https://doi.org/10.31331/jipva.v3i1.778

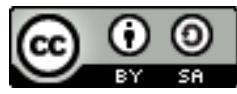




\section{PENDAHULUAN}

IPA merupakan ilmu yang mempelajari fenomena alam yang bersifat faktual dan meliputi empat unsur utama yaitu proses, produk, sikap, dan aplikasi. Proses yaitu prosedur pemecahan masalah melalui metode ilmiah. Produk berupa fakta, prinsip, teori, dan hukum yang digunakan untuk memprediksi gejala alam. Sikap yaitu rasa ingin tahu tentang benda, fenomena alam, makhluk hidup, serta hubungan sebab akibat yang diselidiki dengan sikap ilmiah. Aplikasi yaitu penerapan metode ilmiah dan konsep IPA dalam kehidupan sehari-hari. Unsur-unsur tersebut diharapkan dapat muncul dalam pembelajaran IPA, sehingga peserta didik memperoleh pengetahuan IPA secara utuh (Rahayu, Mulyani, \& Miswadi, 2012).

Pembelajaran IPA berdasarkan kurikulum 2013 mengarah pada proses pembelajaran "integrative Science" atau IPA terpadu. Pembelajaran IPA terpadu merupakan pembelajaran yang memadukan pembelajaran fisika, kimia dan biologi. Pendidikan IPA yang terintegrasi salah satunya memiliki keunggulan dapat menanamkan sikap peduli terhadap lingkungan kepada peserta didik (Lathifah \& Wilujeng, 2016). Sesuai dengan tuntutan kurikulum 2013, pembelajaran IPA menggunakan pendekatan saintifik yang terdiri dari mengamati, menanya, mencoba, menganalisis, dan mengkomunikasikan. Pembelajaran dengan pendekatan saintifik dirancang agar pembelajaran berpusat pada peserta didik dan peserta didik dapat mengembangkan keterampilan proses sehingga dapat mencapai tujuan pembelajaran IPA. Tujuan pembelajaran IPA yang tercantum dalam lampiran Permendikbud No 22 Tahun 2016 yaitu mengembangkan kompetensi sikap, pengetahuan, dan keterampilan secara utuh/holistik (Kementerian pendidikan dan kebudayaan, 2016). Melalui proses pembelajaran kemampuan berpikir peserta didik perlu dikembangkan agar memiliki kemampuan HOTS (Nurwahidah, 2018) sesuai dengan luaran yang diharapkan pada kurikulum 2013. Peserta didik dilatih untuk berpikir serta mampu mengeluarkan ide-ide maupun mengekspresikan diri dalam pembelajaran (Wahyuni \& Kurniawan, 2018).

Hasil observasi di SMPN 3 Trenggalek, proses pembelajaran masih berpusat pada guru. Guru sebagai sumber utama informasi dan pengetahuan yang diperoleh peserta didik. Keadaan ini menyebabkan peserta didik bergantung kepada guru dan pengetahuan yang diperoleh berupa hafalan dari teori dan konsep yang disampaikan guru sehingga kurang memfasilitasi peserta didik untuk aktif dan berpikir secara mandiri. Hal ini sesuai dengan pernyataan Smith, Wood, \& Knight (2008) pada proses pembelajaran guru lebih banyak menyampaikan pembelajaran dengan memberikan materi sebanyak-banyaknya dan berharap peserta didik akan mampu memahami serta menerapkan ilmu yang telah disampaikan dalam kehidupan. Padahal, jika peserta didik terlalu banyak menerima materi tanpa dilakukan penilaian secara kontinu, guru tidak dapat melihat perkembangan kemampuan peserta didik dengan baik.

Pada proses pembelajaran, yang dominan adalah domain kognitif sehingga penilaian yang dilakukan bersifat tradisional dengan paper and pencil test yang hanya mengukur ranah pengetahuan berdasarkan hasil tes saja di setiap akhir kompetensi dasar (KD). Penilaian semacam ini digolongkan penilaian sumatif. Penilaian sebaiknya tidak hanya dilaksanakan saat akhir KD saja, tetapi dilaksanakan sepanjang pembelajaran untuk mengetahui tingkat pemahaman konsep peserta didik terhadap materi yang telah diberikan, hal ini dapat dilakukan dengan mengintegrasikan penilaian formatif (Arifin, 2009). Penilaian penting untuk 
dilakukan agar guru dapat mengukur kemampuan belajar peserta didik (Nurwahidah, 2017). Penilaian formatif memiliki pengaruh terhadap hasil belajar peserta didik (Rapi, 2016).

Guru belum mengintegrasikan penilaian formatif dalam pembelajaran dikarenakan beberapa kendala. Kendala yang dihadapi guru ketika mengintegrasikan penilaian formatif yaitu jumlah peserta didik setiap kelas yang cukup besar menyebabkan guru sering terlambat dalam memberikan umpan balik dan tidak ada tindak lanjut yang spesifik untuk mengatasi kekurangan dan kesulitan yang dialami peserta didik. Kekurangan dan kesulitan yang dialami peserta didik dapat disebabkan oleh sikap peserta didik dalam belajar, cara penyampaian materi oleh guru, dan karakteristik materi. Kesulitan yang dialami peserta didik apabila tidak segera diatasi akan mempengaruhi hasil belajar dan merupakan hambatan untuk mencapai tujuan pembelajaran IPA (Ornek, Robinson, \& Haugan, 2008).

Tercapainya tujuan pembelajaran IPA dapat diketahui dengan melakukan penilaian. Penilaian merupakan salah satu prinsip pengembangan kurikulum 2013 untuk mengetahui dan memperbaiki pencapaian kompetensi peserta didik. Penilaian dalam Kurikulum 2013 menganut prinsip penilaian yang berkelanjutan dan komprehensif guna mendukung upaya memandirikan peserta didik untuk belajar, bekerja sama, dan menilai diri sendiri. Permendikbud No. 66 Tahun 2013 menyebutkan bahwa ada pergeseran dari penilaian tradisional melalui paper and pencil test yang hanya mengukur kompetensi pengetahuan berdasarkan hasil saja, menuju penilaian autentik yang mengukur kompetensi sikap, keterampilan, dan pengetahuan berdasarkan proses dan hasil belajar (Permendikbud, 2013).

Penilaian autentik tidak hanya berfungsi sebagai penilaian sumatif (assessment of learning) namun juga sebagai penilaian formatif (assessment for learning). Penilaian sumatif adalah penilaian yang dilaksanakan pada akhir materi pelajaran, sedangkan penilaian formatif dilaksanakan selama proses pembelajaran. Tujuan penilaian formatif adalah untuk memperbaiki proses pembelajaran dan untuk memperoleh umpan balik. Umpan balik merupakan elemen yang penting dalam penilaian formatif. Umpan balik digunakan guru sebagai dasar untuk memperbaiki proses pembelajaran, memfasilitasi peserta didik tentang apa yang mereka butuhkan untuk belajar, memberikan kesempatan belajar, dan memberikan peserta didik latihan dalam pemecahan masalah (Fakcharoenphol, Potter, \& Stelzer, 2011; Etkina et al., 2006; Ediyanto, 2014).

Guru menggunakan umpan balik tersebut untuk membuat keputusan sehubungan dengan kesiapan, diagnosis, dan remedial. Pentingnya umpan balik bagi peserta didik yaitu dapat menutup kesenjangan pemahaman konsep. Rendahnya pemahaman konsep peserta didik dapat diatasi dengan memberikan umpan balik secara cepat dan tepat melalui penilaian formatif (Cruz, Dias, \& Kortemeyer, 2011; Supardi, 2013). Penelitian sebelumnya menyatakan bahwa penilaian formatif tepat digunakan karena melibatkan peserta didik secara langsung di dalam proses pembelajaran dan mampu meningkatkan pemahaman konsep (Ediyanto, 2014).

Menurut Saptono, Rustaman, Saefudin, dan Widodo (2013) pengembangan model integrasi atribut asesmen formatif (IAAF) dapat mengembangkan kemampuan bernalar dan berpikir analitik mahasiswa calon guru. Penilaian formatif meningkatkan pemahaman konsep peserta didik dan memberikan masukan tentang apa saja yang perlu diupayakan untuk mendapatkan pemahaman konsep yang lebih dalam (Arifin, 2009; Saptono et al., 2013; 
Tanner \& Allen, 2004; Furtak \& Ruiz-Primo, 2008). Penilaian formatif mampu membantu peserta didik untuk mendapatkan pamahaman konsep melalui feedback. Pentingnya feedback ini bagi peserta didik untuk memotivasi dan merefleksi kegiatan belajar (Irons, 2008).

Dampak penilaian formatif memiliki efek positif terhadap pencapaian nilai akademik peserta didik dilihat dari hasil pretest dan posttest yang menghasilkan skor yang cukup tinggi dibanding tanpa menerapkan penilaian formatif (Mehmood, Hussain, Khalid, \& Azam, 2012). Penerapan penilaian formatif dapat meningkatkan kemampuan self regulation dan prestasi akademik peserta didik yang diukur melalui hasil pretest dan posttest peserta didik (Rahmawati, Hartono, \& Nugroho, 2015). Ada pengaruh yang signifikan pemberian tes formatif terhadap peningkatan hasil belajar yang diukur dengan menggunakan nilai pretest dan posttest, peserta didik yang menerima tes formatif memiliki nilai rata-rata yang lebih tinggi dari pada peserta didik yang tidak menerima tes formatif (Khafid \& Nurhayati, 2014). Oleh sebab itu penelitian ini bertujuan untuk mengetahui pengaruh pengintegrasian penilaian formatif dalam pembelajaran IPA berbasis pendekatan saintifik terhadap pemahaman konsep peserta didik.

\section{METODE}

\section{Jenis Penelitian}

Jenis penelitian ini merupakan penelitian eksperimen semu (quasi experimental design). Desain penelitian yang digunakan adalah posttest-only group design. Rancangan penelitian selengkapnya dapat dilihat pada Tabel 1.

Tabel 1. Rancangan penelitian

\begin{tabular}{lll}
\hline Kelas & Perlakuan & Posttest \\
\hline Eksperimen & $X_{1}$ & $O$ \\
Kontrol & $X_{2}$ & $O$ \\
\hline
\end{tabular}

Keterangan:

$\mathrm{X}_{1}=$ Perlakuan menggunakan pendekatan saintifik yang diintegrasikan dengan penilaian formatif formal dan informal

$\mathrm{X}_{2}=$ Perlakuan menggunakan pendekatan saintifik yang diintegrasikan dengan penilaian formatif informal

$\mathrm{O}=$ Nilai posttest

\section{Waktu dan Tempat Penelitian}

Penelitian dilaksanakan di SMPN 3 Trenggalek pada semester genap tahun pelajaran 2017/2018.

\section{Subjek Penelitian}

Populasi dalam penelitian ini adalah peserta didik kelas VIII SMPN 3 Trenggalek semester genap tahun pelajaran 2017/2018. Jumlah peserta didik kelas VIII sebanyak 226 dengan jumlah peserta didik laki-laki sebanyak 86 dan perempuan sebanyak 140.

Pengambilan sampel dilakukan dengan teknik purposive sampling. Sampel yang dipilih adalah dua kelas yang memiliki kemampuan relatif sama berdasarkan nilai UTS. Kelas pertama sebagai kelas eksperimen (VIII D) sedangkan kelas kedua sebagai kelas kontrol (VIII E). Jumlah peserta didik kelas VIII D sebanyak 32 dengan jumlah peserta didik laki-laki 14 
dan peserta didik perempuan 18. Jumlah peserta didik kelas VIII E sebanyak 32 dengan jumlah peserta didik laki-laki 8 dan peserta didik perempuan 24. Kelas eksperimen menggunakan pendekatan saintifik yang diintegrasikan penilaian formatif formal dan informal dalam pembelajaran dan kelas kontrol menggunakan pendekatan saintifik yang diintegrasikan penilaian formatif informal.

\section{Prosedur}

Tahapan pada penelitian ini ada tiga, yaitu tahap pra penelitian, tahap pelaksanaan, dan tahap akhir. Tahap pra penelitian dilakukan untuk perencanaan dan persiapan penelitian sebagai berikut: (1) Mengkaji kompetensi inti dan kompetensi dasar materi IPA pada kelas VIII semester genap; (2) Studi literatur mengenai penilaian formatif; (3) Menyusun instrumen perlakuan (silabus, RPP, dan LKPD) dan instrumen pengukuran (soal pemahaman konsep dan lembar observasi keterlaksanaan pengintegrasian penilaian formatif); dan (4) Memvalidasi instrumen perlakuan dan soal pemahaman konsep yang akan digunakan saat penelitian.

Tahap pelaksanaan penelitian kegiatan yang dilakukan pada tahap ini sebagai berikut: (1) Menentukan kelas yang akan dijadikan sebagai kelas eksperimen dan kelas control; (2) Melakukan pembelajaran berbasis saintifik di masing-masing kelas; (3) Memberikan perlakuan penilaian formatif formal (memberikan soal formatif berupa soal uraian di tiap akhir pembelajaran) dan informal pada kelas eksperimen dan memberikan perlakuan penilaian formatif informal pada kelas kontrol; dan (4) Memberikan soal pemahaman konsep pada kelas eksperimen dan kontrol di akhir KD.

Pada tahap akhir kegiatan yang dilakukan adalah menganalisis data penelitian berupa hasil posttest yang telah dikerjakan peserta didik pada kelas eksperimen dan kelas kontrol. Kemudian membahas hasil penelitian yang diperoleh dan terakhir menarik kesimpulan.

\section{Data, Instrumen, dan Teknik Pengumpulan Data}

Instrumen penelitian yang digunakan untuk mengumpulkan data pada penelitian ini berupa instrumen perlakuan dan instrumen pengukuran. Instrumen perlakuan merupakan instrumen yang digunakan untuk memberikan perlakuan kepada kelompok penelitian. Instrumen perlakuan yang digunakan dalam penelitian terdiri dari silabus, Rencana Pelaksanaan Pembelajaran (RPP), Lembar Kerja Peserta Didik (LKPD).

Instrumen pengukuran merupakan instrumen yang digunakan untuk mengukur keterlaksanaan pengintegrasian penilaian formatif. Instrumen pengukuran dalam penelitian terdiri dari instrumen non tes berupa lembar observasi keterlaksanaan pengintegrasian penilaian formatif dan tes berupa soal pemahaman konsep dengan tipe soal pilihan ganda pada ranah kognitif $\mathrm{C}_{2}$ (memahami).

\section{Teknik Analisis Data}

Teknik analisis data penelitian meliputi uji prasyarat dan uji hipotesis. Uji prasyarat yang dilakukan adalah uji normalitas, uji homogenitas varian, dan uji kesamaan rata-rata kemampuan awal. Uji hipotesis yang dipilih yakni uji-t dua pihak.

Uji normalitas yang digunakan untuk menganalisis data kelas eksperimen dan kelas kontrol adalah uji Lilifors. Jenis uji homogenitas yang digunakan dalam penelitian ini adalah uji Bartlett. Uji kesamaan rata-rata kemampuan awal bertujuan untuk mengetahui apakah dua kelompok yang digunakan dalam penelitian memiliki kemampuan awal yang sama atau tidak. 
Uji kesamaan rata-rata kemampuan awal dilakukan dengan melihat hasil rata-rata ujian peserta didik pada materi sebelumnya.

Hasil uji prasyarat menunjukkan data terdistribusi normal dan homogen, sehingga uji hipotesis dihitung menggunakan uji-t dua pihak (two tail test). Uji-t dua pihak dilakukan dengan bantuan microsoft excel 2010. Uji-t dilakukan untuk mengetahui perbedaan antara dua sampel yang diberikan perlakuan dengan $p<0,05$.

\section{HASIL DAN PEMBAHASAN}

Hasil rata-rata skor posttest pemahaman konsep peserta didik yang diukur dengan menggunakan soal pemahaman konsep pada kelas eksperimen dan kelas kontrol dapat dilihat pada Tabel 2.

Tabel 2. Skor rata-rata posttest

\begin{tabular}{ll}
\hline Kelas & Rata-Rata Posttest \\
\hline Eksperimen & 77,22 \\
Kontrol & 67,50 \\
\hline \multicolumn{1}{c}{ Rata-rata nilai pemahaman konsep peserta didik pada kelas eksperimen dan kontrol }
\end{tabular}

Rata-rata nilai pemahaman konsep peserta didik pada kelas eksperimen dan kontrol 77,22 > 67,50 rata-rata nilai kelas eksperimen lebih tinggi daripada kelas kontrol. Integrasi penilaian formatif formal pada kelas eksperimen merupakan salah satu penyebab perbedaan perolehan hasil posttest pemahaman konsep antara kelas kontrol dan kelas eksperimen. Hal ini sesuai dengan penelitian Saptono et al., (2013) serta Ediyanto (2014) yaitu dengan penerapan penilaian formatif dapat meningkatkan kemapuan berpikir dan pemahaman konsep peserta didik. Pengintegrasian penilaian formatif formal dilaksanakan dengan mengerjakan soal kuis yang telah disediakan. Soal kuis yang diberikan oleh guru terdiri dari 4 sampai 5 butir soal dalam bentuk uraian yang diberikan setiap akhir proses pembelajaran. Tes uraian memberikan kebebasan kepada peserta didik dalam memberikan jawaban dengan pemikiran yang lebih kompleks (Sasongko, 2010). Tes uraian lebih efektif digunakan dalam mengevaluasi hasil pembelajaran (Sasongko, 2010; Siswaningsih, Dwiyanti, \& Gumilar, 2013; Romah \& Nurhayati, 2017). Tes formatif dengan bentuk uraian dapat meningkatkan hasil belajar peserta didik (Siswaningsih et al., 2013). Tes formatif juga meningkatkan minat belajar peserta didik dalam mendengarkan dan memperhatikan materi yang sedang diajarkan (Bayat, Jamshidipour, \& Hashemi, 2017). Hasil perolehan nilai rata-rata tes formatif dapat dilihat pada Tabel 3.

Tabel 3. Hasil rata-rata tes formatif

\begin{tabular}{ccc}
\hline Kuis & Rerata & Ketercapaian (\%) \\
Kuis 1 & 63,84 & 64 \\
Kuis 2 & 70,44 & 70 \\
Kuis 3 & 75,06 & 75 \\
Kuis 4 & 77,38 & 77 \\
Kuis 5 & 78,75 & 79 \\
Rerata & 73,09 & 73 \\
\hline
\end{tabular}

Berdasarkan Tabel 3, secara umum hasil kuis peserta didik di setiap pertemuan menunjukkan hasil yang cukup baik dan menunjukkan peningkatan. Kuis pertama rata-rata nilai peserta didik 64 karena pada kuis pertama peserta didik merasa terkejut dan belum siap. 
Pada pertemuan kedua rata-rata nilai peserta didik mengalami peningkatan menjadi 70. Pada pertemuan ketiga rata-rata nilainya meningkat menjadi 75 hal ini dikarenakan peserta didik mulai terbiasa dengan kuis yang diberikan dan membuat peserta didik selama pembelajaran bersikap serius dan memperhatikan setiap penjelasan dari guru. Pada pertemuan keempat mendapat rata-rata 77 sebagian besar peserta didik merasa senang dengan pelajaran mata sebagai alat optik karena objek pembelajaran bersifat konkret. Selanjutnya pertemuan terakhir rata-rata nilai yang diperoleh sebesar 79. Mengacu pada peningkatan rata-rata skor dari kuis dapat disimpulkan bahwa peningkatan ini terjadi sebagai bentuk diterapkannya penilaian formatif dalam pembelajaran (Irons, 2008). Peserta didik merasa senang karena disetiap pembelajaran guru selalu menilai hasil pekerjaan mereka dan mendapat umpan balik serta perbaikan dari guru jika terdapat konsep berpikir yang belum sesuai. Adanya pemberian umpan balik yang dilakukan oleh guru secara cepat dan tepat melalui penilaian formatif mampu meningkatkan pemahaman konsep peserta didik (Cruz et al., 2011). Umpan balik ini nantinya digunakan sebagai dasar untuk memperbaiki proses pembelajaran, memfasilitasi peserta didik tentang apa yang mereka butuhkan untuk belajar, memberikan kesempatan belajar, dan memberikan peserta didik latihan dalam pemecahan masalah (Fakcharoenphol et al., 2011; Etkina et al., 2006; Siswaningsih et al., 2013).

Umpan balik yang baik adalah berdasarkan hasil perolehan skor kuis peserta didik dapat membantu guru memotivasi peserta didik untuk lebih fokus belajar dengan memberi saran dan perbaikan sehingga peserta didik termotivasi untuk meningkatkan kualitas belajarnya (Grant, 2017; Saptono et al., 2013; Lathifah \& Wilujeng, 2016). Menurut Afriana, Permanasari, \& Fitriani (2016) pembelajaran dengan atribut asesmen formatif dapat mengembangkan penalaran berpikir mahasiswa calon guru biologi. Guru sebaiknya tidak menggunakan perolehan skor kuis peserta didik untuk membandingkan kemampuan peserta didik yang satu dengan peserta didik lainnya, karena hal tersebut dapat menimbulkan rasa minder dan malu bagi peserta didik yang memiliki kemampuan kurang. Penerapan penilaian formatif dapat membantu guru memperoleh umpan balik yang dapat digunakan untuk melakukan perbaikan pada kualitas pembelajaran sehingga dapat meningkatkan aktivitas serta hasil belajar peserta didik (Saptono et al., 2013).

Berbeda dengan kelas eksperimen, pada kelas kontrol kegiatan tes dilakukan setelah peserta didik menyelesaikan satu kompetensi dasar. Kegiatan tes sumatif yang diberikan kepada peserta didik kelas kontrol menunjukkan hasil yang berbeda dengan hasil tes kelas eksperimen. Pada saat peserta didik menyelesaikan tes sumatif, banyak peserta didik yang sudah lupa akan materi yang telah mereka pelajari, hal ini menyebabkan banyak peserta didik menjawab salah sehingga mempengaruhi nilai hasil perolehan tes sumatif peserta didik menjadi rendah. Rendahnya hasil sumatif disebabkan karena jeda waktu mempelajari materi dengan waktu pelaksanaan tes sumatif yang lama dan materi yang dipelajari luas. Perolehan nilai rata-rata hasil tes sumatif peserta didik dilihat pada Tabel 4.

Tabel 4. Hasil rata-rata tes sumatif

\begin{tabular}{lll}
\hline Kegiatan & Rerata & Persentase (\%) \\
Sumatif 1 & 53,50 & 54 \\
Sumatif 2 & 64,09 & 64 \\
Rerata & 58,79 & 59 \\
\hline
\end{tabular}


Berdasarkan Tabel 4, hasil rata-rata perolehan nilai diketahui bahwa tes sumatif sangat menyulitkan peserta didik. Dikatakan menyulitkan karena materi pelajaran satu kompetensi dasar sangat luas yang dipelajari sampai 5 kali pertemuan. Setelah selesai pertemuan semua materi pembelajaran satu KD, baru dilaksanakan tes sehingga hasilnya jauh dari tujuan yang hendak dicapai. Tujuan yang hendak dicapai dari kegiatan evaluasi adalah mengukur sejauh mana kemampuan peserta didik dalam mempelajari suatu materi pembelajaran pada rentang waktu yang telah ditetapkan.

Tes sumatif yang dilaksanakan seharusnya satu kali di akhir selesainya satu kompetensi dasar, tetapi guru melaksanakan dua kali tes sumatif. Sumatif pertama dilaksanakan setelah menyelesaikan materi cemin datar sampai dengan lensa dengan perolehan nilai rata-rata 53,50 yang berarti hanya 10 orang peserta didik dari 32 peserta didik yang memperoleh nilai sesuai standar minimal 65. Tes sumatif kedua dilakukan setelah menyelesaikan seluruh materi mata dan alat optik, rata-rata yang diperoleh 64,09 yang berarti hanya 20 orang peserta didik dari 32 peserta didik yang memperoleh nilai sesuai standar minimal 65. Peningkatan terjadi dikarenakan jeda antar materi tidak begitu jauh. Berdasarkan rata-rata nilai pada sumatif pertama dan kedua dapat dikatakan belum mencapai tujuan pembelajaran yang diharapkan. Tujuan pembelajaran yang diharapkan yaitu peserta didik mampu mencapai standar ketuntasan minimal yang ditentukan oleh pihak sekolah yakni memperoleh nilai terendah 65 .

Pada saat pelaksanaan tes sumatif peserta didik mengeluh dan merasa kesulitan menyelesaikan soal, hal ini dikarenakan peserta didik dipaksa mempelajari materi yang begitu banyak dalam waktu yang singkat. Hilgard \& Bowler (1977) menjelaskan bahwa pengetahuan yang diterima melalui panca indra akan direkam menuju ingatan jangka panjang, pengetahuan yang tidak diulang-ulang dan tidak mendapat perhatian akan terdorong keluar dan terlupakan. Pernyataan ini didukung oleh Worrel \& Stilwell (1981) yang menyatakan bahwa untuk mencegah proses lupa pada peserta didik maka perlu diberikan ujian secepatnya. Hal ini dapat dilakukan dengan mengintegrasikan penilaian formatif formal dalam pembelajaran. Penilaian ini dilakukan untuk mengetahui sejauh mana peserta didik telah memahami materi pelajaran dan untuk mengetahui kelemahan proses pembelajaran seperti ketepatan penggunaan metode, media, dan sistem penilaian yang digunakan.

Hal lain yang juga merupakan salah satu penyebab perbedaan perolehan hasil posttest pemahaman konsep antara kelas kontrol dan kelas eksperimen yaitu peserta didik menuliskan kesimpulan pembelajaran, menuliskan apa saja yang yang telah diperoleh selama belajar, serta materi mana yang belum dikuasai. Berdasarkan hal itu guru dapat memantau peserta didik dan dapat memahami kelemahan peserta didik terhadap suatu pokok bahasan. Guru melakukan pengulangan apabila masih ada materi yang belum dipahami peserta didik.

Pada proses pembelajaran guru juga memberikan motivasi kepada peserta didik. Pemberian motivasi dilakukan untuk meningkatkan semangat belajar peserta didik, karena tidak jarang sebagian besar peserta didik merasa malas, jenuh, bersenda gurau, atau tertidur di dalam kelas. Pemberian motivasi ini diharapkan mampu memberikan stimulasi positif terhadap cara berpikir peserta didik. Akumulasi dari perkataan-perkataan positif yang terus menerus dilontarkan dan didengar oleh peserta didik akan membuat cara berpikirnya menjadi lebih positif dan yakin dengan kemampuan dirinya sendiri, sehingga perasaan pesimis dan rendah diri yang selama ini dirasakan bisa berubah menjadi optimisme yang kuat. 


\section{SIMPULAN DAN SARAN}

\section{Simpulan}

Berdasarkan hasil penelitian disimpulkan bahwa pengintegrasian penilaian formatif formal dan informal dalam pembelajaran IPA berbasis pendekatan saintifik memberikan pengaruh yang signifikan terhadap peningkatan pemahaman konsep peserta didik. Peserta didik pada kelas eksperimen memiliki nilai pemahaman konsep yang tinggi dibanding dengan kelas kontrol. Dengan demikian pengintegrasian penilaian formatif formal dan informal dalam pembelajaran IPA berbasis pendekatan saintifik dapat digunakan guru untuk meningkatkan pemahaman konsep peserta didik.

\section{Saran}

Pembelajaran dengan menerapkan penilaian formatif guru dituntut memberikan feedback secara langsung/cepat dan disampaikan pada saat pembelajaran. Apabila terlambat dan menunda feedback pada pertemuan selanjutnya akan berdampak pada self-assessment (refleksi) peserta didik dalam kegiatan belajar. Pelaksanaan penelitian lebih lanjut untuk mengetahui dampak integrasi penilaian formatif terhadap pemahaman konsep peserta didik, perlu mempertimbangkan cara agar dapat memberikan feedback dengan cepat dan tepat.

\section{DAFTAR PUSTAKA}

Afriana, J., Permanasari, A., \& Fitriani, A. (2016). Project based learning integrated to STEM to enhance elementary school's students scientific literacy. Jurnal Pendidikan IPA Indonesia, 5(2), 261-267. https://doi.org/10.15294/jpii.v5i2.5493

Arifin, Z. (2009). Evaluasi pembelajaran. Bandung: PT Remaja Rosdakarya.

Bayat, A., Jamshidipour, A., \& Hashemi, M. (2017). The beneficial impacts of applying formative assessment or Iranian University student's anxiety reduction and listening efficacy. International Journal of Languages' Education and Teaching, 5(2), 1-11. https://doi.org/10.18298/ijlet.1740

Cruz, E., Dias, H., \& Kortemeyer, G. (2011). The effect of formative assessment in Brazilian university physics courses. Revista Brasileira de Ensino de Física, 33(4), 1-7. https://doi.org/10.1590/S1806-11172011000400016

Ediyanto. (2014). Pengembangan model penilaian formatif berbasis web untuk meningkatkan pemahaman konsep fisika siswa. Jurnal Pendidikan Sains, 2(2), 63-75. https://doi.org/10.17977/jps.v2i2.4499

Etkina, E., Heuvelen, A. Van, White-brahmia, S., Brookes, D. T., Gentile, M., Murthy, S., ... Warren, A. (2006). Scientific abilities and their assessment. Physics Education Research, 2(2), 1-15. https://doi.org/10.1103/PhysRevSTPER.2.020103

Fakcharoenphol, W., Potter, E., \& Stelzer, T. (2011). What students learn when studying physics practice exam problems. Physics Education Research, 7(1), 1-7. https://doi.org/10.1103/PhysRevSTPER.7.010107

Furtak, E. M., \& Ruiz-Primo, M. A. (2008). Making Students' Thinking Explicit in Writing and Discussion: An analysis of formative assessment prompts. Science Education, 92(5), 798-824. https://doi.org/10.1002/sce.20270

Grant, P. F. (2017). Formative test-driven development for programming practicals. AISHE-J, 
9(2). Retrieved from http://ojs.aishe.org/index.php/aishe-j/article/view/302

Hilgard, E., \& Bowler, G. (1977). Theory of learning. New Delhi: Prentice Hallof India Privated Ltd.

Irons, A. (2008). Enhancing learning through formative assessment and feedback. Oxon: Routledge.

Kementerian pendidikan dan kebudayaan. (2016). Standar proses pendidikan dasar dan menengah. Jakarta: Kemendikbud.

Khafid, M., \& Nurhayati, F. (2014). Pengaruh pemberian tes formatif terhadap peningkatan hasil belajar pendidikan kesehatan pada siswa kelas VII SMP Negeri 2 Krian. Jurnal Pendidikan Olahraga Dan Kesehatan, 2(1), 119-124. Retrieved from http://ejournal.unesa.ac.id/index.php/jurnal-pendidikan-jasmani/issue/archive

Lathifah, I. N., \& Wilujeng, I. (2016). Pengembangan Perangkat Pembelajaran Integrated Science Berbasis Kearifan Lokal The Development of Learning Kit of Integrated Science Based on Local Wisdom. Jurnal Pendidikan Matematika Dan Sains, 4(2), 120-129. https://doi.org/10.21831/jpms.v4i2.12943

Mehmood, T., Hussain, T., Khalid, M., \& Azam, R. (2012). Impact of formative assessment on academic achievement of secondary school students. International Journal of Business and Social Science, 3(17), 101-104. Retrieved from http://ijbssnet.com/journal/index/1511

Nurwahidah, I. (2017). Penggunaan asesmen pembelajaran IPA bagi siswa visual impairment di SLB Jawa Tengah. JIPVA (Jurnal Pendidikan IPA Veteran), 1(1), 39-50. Retrieved from http://e-journal.ivet.ac.id/index.php/jipva/article/view/517

Nurwahidah, I. (2018). Pengembangan soal penalaran model TIMSS untuk mengukur high order thinking (HOT). Thabiea: Journal of Natural ScienceTeaching, 1(1), 20-29. https://doi.org/10.21043/thabiea.v1i1.3874

Ornek, F., Robinson, W. R., \& Haugan, M. P. (2008). What makes physics difficult? International Journal of Environmental \& Science Education, 3(1), 30-34. Retrieved from http://www.ijese.net/makale/1594

Rahayu, P., Mulyani, S., \& Miswadi, S. S. (2012). Pengembangan pembelajaran IPA terpadu dengan menggunakan model pembelajaran proble base melalui lesson study. Jurnal Pendidikan IPA Indonesia, 1(1), 63-70. https://doi.org/10.15294/jpii.v1i1.2017

Rahmawati, I. L., Hartono, \& Nugroho, S. E. (2015). Pengembangan asesmen formatif untuk meningkatkan kemampuan self regulation siswa pada tema suhu dan perubahannya. Unnes Science Education Journal, 4(2), 842-850. https://doi.org/10.15294/usej.v4i2.7922

Rapi, N. K. (2016). Pengaruh model pembelajaran dan jenis penilaian formatif terhadap hasil belajar IPA siswa SMPN. Jurnal Cakrawala Pendidikan, 35(1), 69-79. https://doi.org/10.21831/cp.v1i1.8366

Romah, U. M., \& Nurhayati, F. (2017). Pengaruh pemberian tes formatif terhadap peningkatan hasil belajar pendidikan kesehatan. Jurnal Pendidikan Olahraga Dan Kesehatan, 5(3), 844-850. Retrieved from https://jurnalmahasiswa.unesa.ac.id/index.php/jurnal-pendidikanjasmani/article/view/21439

Saptono, S., Rustaman, N. Y., Saefudin, \& Widodo, A. (2013). Model integrasi atribut 
asesmen formatif (IAAF) dalam pembelajaran biologi sel untuk mengembangkan kemampuan penalaran dan berpikir analitik mahasiswa calon guru. Jurnal Pendidikan IPA Indonesia, 2(1), 31-40. https://doi.org/10.15294/jpii.v2i1.2507

Sasongko, P. (2010). Perbandingan keefektifan bentuk tes uraian dan testlet dengan penerapan graded response model (GRM). Jurnal Penelitian Dan Evaluasi Pendidikan, 14(2), 269288. https://doi.org/10.21831/pep.v14i2.1082

Siswaningsih, W., Dwiyanti, G., \& Gumilar, C. (2013). Penerapan peer assessment dan self asssessment pada tes formatif hidrokarbon untuk feedback siswa SMA kelas X. Jurnal Pengajaran MIPA, 18(1), 107-115. https://doi.org/10.18269/jpmipa.v18i1.263

Smith, M. K., Wood, W. B., \& Knight, J. K. (2008). The genetics consept assessmet: a new consept inventory for gauging student undertanding of genetics. CBE-Life Science Education, 7, 422-430. https://doi.org/10.1187/cbe.08

Supardi, S. U. S. (2013). Hasil belajar matematika siswa ditinjau dari interaksi tes formatif uraian dan kederdasan emosionla. Jurnal Fomatif, 3(2), 78-96. https://doi.org/10.30998/formatif.v3i2.115

Tanner, K., \& Allen, D. (2004). Approaches to Biology Teaching and Learning: From Assays to Assessments-On Collecting Evidence in Science Teaching. Cell Biology Education, 3(2), 69-74. https://doi.org/10.1187/cbe.04-03-0037

Wahyuni, A., \& Kurniawan, P. (2018). Hubungan kemampuan berpikir kreatif terhadap hasil belajar mahasiswa. Jurnal Matematika, 17(2), 1-8. Retrieved from https://ejournal.unisba.ac.id/index.php/matematika/article/view/4114

Worrel, \& Stilwell. (1981). Educational assessment of education. New Jersey: Prentice Hall.

\section{PROFIL SINGKAT}

Intan Puspita Sari dilahirkan di Trenggalek pada tanggal 26 Mei 1995. Penulis menempuh pendidikan dasar di SDN 1 Buluagung, Kecamatan Kedungsangkal, Kabupaten Trenggalek lulus pada tahun 2007. Pendidikan menengah pertama ditempuh di SMPN 3 Trenggalek lulus pada tahun 2010. Pendidikan menengah atas ditempuh di SMAN 1 Trenggalek lulus pada tahun 2013. Setelah lulus dari sekolah menegah pertama melanjutkan studi di perguruan tinggi swasta di malang yaitu di Universitas Kanjuruhan Malang terdaftar sebagai mahasiswi S1 Program Sarjana Pendidikan Matematika angkatan 2013 dan juga terdaftar sebagai mahasiswi S1 Program Sarjana Pendidikan Ilmu Pengetahuan Alam angkatan 2014 yang ditempuh di Universitas Negeri Malang. Aktivitas saat ini adalah mengajar di SMPN 5 Malang.

Vita Ria Mustikasari, S.Pd., M.Pd lahir di Banyuwangi pada tanggal 30 April 1986. Pendidikan S1 di tempuh di Jurusan Fisika Program Studi Pendidikan Fisika UM lulus tahun 2008 dan pendidikan S2 di tempuh di program pascasarjana UM program studi pendidikan fisika lulus tahun 2013. Saat ini aktif menjadi dosen prodi pendidikan IPA FMIPA UM.

Novida Pratiwi, S.Si., M.Sc. lahir di Malang pada tanggal 3 November 1986. Pendidikan S1 di tempuh di Jurusan Biologi Program Studi Biologi UM lulus tahun 2008 dan pendidikan S2 di tempuh di pascasarjana UGM fakultas biologi lulus tahun 2011. Saat ini aktif menjadi dosen prodi pendidikan IPA FMIPA UM. 